\title{
Структурные связи эклогитсодержащих комплексов севера Урала с кристаллическим фундаментом Печорской плиты
}

\author{
C2021 Т. А. Пономарева ${ }^{\bowtie}$, А. М. Пыстин \\ Институт геологии им. академика Н.П. Юшкина ФИЦ КНЦ УрО РАН, ул. Первомайская \\ 54, 167982, ГСП-2, Сыктывкар, Российская Федерация
}

\begin{abstract}
Аннотация
Введение: На севере Урала эклогиты установлены в двух метаморфических комплексах: марункеуском эклогит-гнейсовом на Полярном Урале и неркаюском эклогит-сланцевом на Приполярном Урале. Выявлены признаки северо-западной и субширотной ориентировки аномалий геофизических полей над эклогитсодержащими комплексами севера Урала и их пространственные взаимосвязи. Структурные особенности и геологические взаимоотношения комплексов с окружающими толщами дают основание для гипотезы о принадлежности марункеуского и неркаюского комплексов к фрагментам раннедокембрийского основания, вовлеченного в структуру Уралид. Приводится комплексная интерпретация геофизических полей по марункеускому и неркаюскому комплексам. Рассматриваются возможные глубинные связи высокобарических объектов и кристаллического фундамента прилегающей с запада платформенной области.

Методика исследований: Обобщены и систематизированы материалы по комплексной интерпретации геофизических полей (гравитационного, сейсмического), позволяющие решить вопрос о глубине залегания источников аномалий над эклогитсодержащими комплексами. Основное внимание уделено анализу трансформированных карт и построению методом подбора комплексных моделей земной коры, а также геологической интерпретации глубинных структур.

Результаты и обсуждения: В процессе интерпретации гравитационного поля выявлены схожие черты в строении марункеуского эклогит-гнейсового и неркаюского эклогит-сланцевого комплексов. Установлена приуроченность локальных максимумов силы тяжести к участкам распространения пород основного (и частично ультраосновного в марункеуском комплексе) состава. Изучение структуры локальных полей по интенсивности, размерам и линейной северо-западной направленности аномальных зон и подзон Печорской плиты и эклогитсодержащих комплексов севера Урала позволяет установить пространственную взаимосвязь между ними на уровне средней коры.

Заключение. Выявленные пространственные связи дают возможность считать наиболее аномальные участки над марункеуским эклогит-гнейсовым и неркаюским эклогит-сланцевым комплексами юговосточным продолжением Варандей-Адзьвинской зоны и Верхнеколвинской подзоны интенсивных положительных гравитационных аномалий Печорской плиты. Полученные геолого-геофизические данные подтверждают представление о марункеуском и неркаюском комплексах, как фрагментах раннедокембрийского основания, вовлеченного в структуру Уралид.

Ключевые слова: геофизические поля, север Урала, марункеуский, неркаюский, комплекс, глубинное строение, аномалия, разлом, зона.
\end{abstract}

Источник финансирования: Работа выполнена при поддержке программ НИР ГР №АААА-А17117121270035-0.

Контент доступен под лицензией Creative Commons Attribution 4.0 License.

\footnotetext{
Пономарева Татьяна Анатольевна, e-mail: taponomareva@inbox.ru
} 
Для цичтирования: Пономарева Т. А., Пыстин А. М. Структурные связи эклогитсодержащих комплексов севера Урала с кристаллическим фундаментом Печорской плиты // Вестник Воронежского государственного университета. Серия: Геология. 2021. №1. С. 6574. DOI: https://doi.org/10.17308/geology.2021.1/3338

\section{Введение}

На Урале основные проявления высокобарических метаморфитов образуют так называемый высокобарический пояс, который прослеживается вдоль Главного Уральского разлома от р. Щурья на севере до р. Урал на юге на расстоянии 2000 км. В пределах этого пояса возрастные датировки, полученные по высокобарическим метаморфитам, в основном, укладываются в интервал 390-240 млн лет. Учитывая четкий структурный контроль высокобарического метаморфизма (приуроченность к Главному Уральскому разлому) и преобладающие возрастные оценки, многие исследователи ограничивают указанным выше интервалом время формирования высокобарических породных ассоциаций, начиная с процессов кристаллизации высокобарических парагенезисов в глубинных зонах и заканчивая эксгумацией метаморфитов в коллизионный и постколлизионный этапы развития Уральского складчато-орогенного пояса.

В то же время, наиболее высокотемпературные разновидности высокобарических метаморфитов - эклогиты, хотя и расположены в пределах высокобарического пояса, но в отличие от преобладающих в его составе глаукофановых сланцев, имеют очень ограничен-

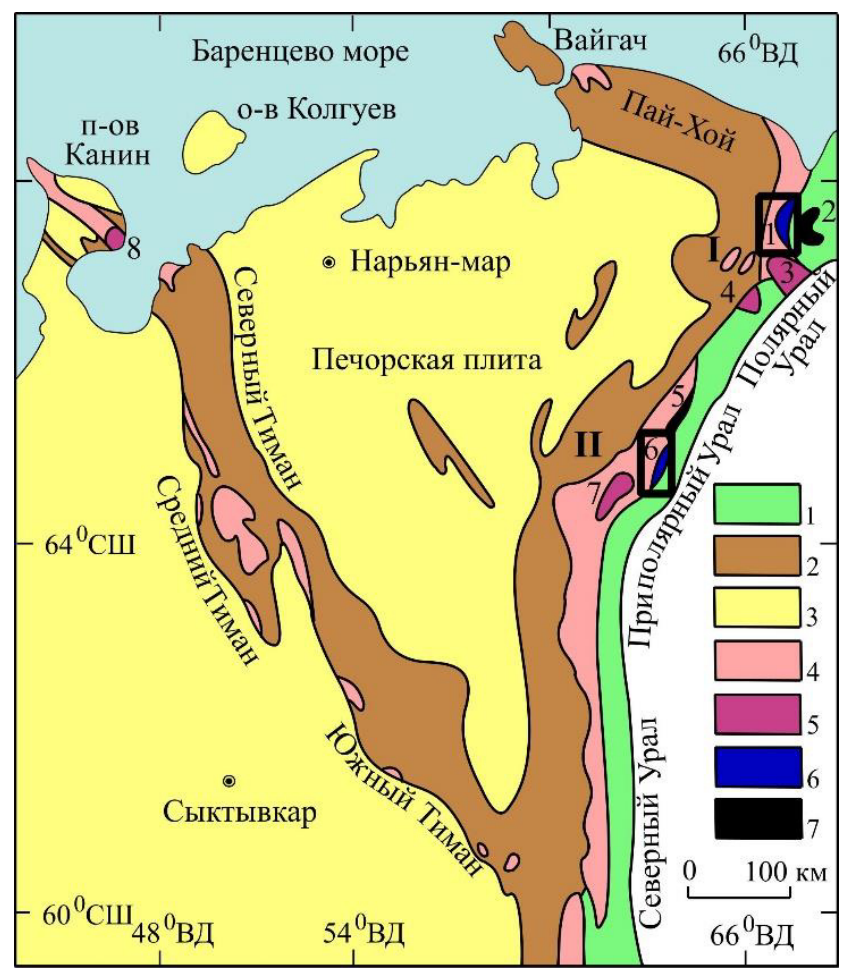

ное распространение. Так, в северной части Урала эклогиты установлены только в двух метаморфических комплексах: марункеуском эклогит-гнейсовом на Полярном Урале [1] и неркаюском эклогит-сланцевом на Приполярном Урале [2]. Обращает на себя внимание, что эти комплексы приурочены к двум основным выходам нижнего докембрия, обнажающимся в крупных поперечных поднятиях, соответственно, Собском на Полярном Урале и Кожимском на Приполярном Урале (рис. 1). Как и нижнедокембрийские гнейсо-мигматитовые и гранулит-метабазитовые комплексы в этой части Урала (харбейский, малыкский, хордъюский и няртинский), рассматриваемые высокобарические комплексы характеризуются «неуральской» ориентировкой наиболее ранних картируемых структур: преимущественно северо-западной [2, 3]. В последние годы в результате комплексного анализа петрофизических и гравимагнитных данных в разрезе эклогитсодержащих комплексов севера Урала установлены признаки северо-западной и субширотной ориентировки аномалий магнитного поля и плотностных неоднородностей земной коры $[4,5,6]$. Пространственная связь гнейсо-мигматитовых, гранулит-метабазитовых и эклогитсодержащих комплексов севера Урала, их структурные особенности и геологические взаимоотношения с окружающими толщами дают основание для поддержания гипотезы о принадлежности марункеуского и неркаюского комплексов к фрагментам раннедокембрийского основания, вовлеченного в структуру Уралид $[7,8,9]$. Изучением и обобщением информации по глубинному строению севера Урала в последние десятилетия занимаются специалисты Института физики Земли РАН,

Рис. 1. Схема геологического строения Тимано-Североуральского региона. Условные обозначения: 1-2 - палеозойские формации Урала и Тимана: 1 - палеоокеанические, 2 палеоконтинентальные; 3 - платформенный чехол ВосточноЕвропейской платформы и Печорской плиты; 4 - мезонеопротерозойские формации; 5-7 - нижнедокембрийские метаморфические комплексы: 5 - гнейсовые и гнейсо-мигматитовые комплексы, 6 - эклогит-гнейсовые и эклогит-сланцевые, 7 - гранулит-метабазитовые. Названия нижнедокембрийских метаморфических комплексов: 1 - марункеуский, 2 - малыкский, 3 - харбейский, 4 - хараматалоуский, 5 хордъюский, 6 - неркаюский, 7 - няртинский, 8 - микулкинский. Уральские поперечные поднятия: $I$ - Собское, $I I$ - Кожимское. Прямоугольниками выделены районы исследований.

[Fig. 1. Geological structure of the Timan-North-Urallian region. Legend: 1-2 - Paleozoic formations of the Urals and Timan Ridge: 1 -paleoceanic, 2 -paleocontinental; 3 -platform cover of the East European platform and the Pechora Plate; 4 - Meso Neoproterozoic formations; 5-7 - Lower Precambrian metamorphic complexes: 5 - gneiss and gneiss - migmatite complexes, 6 - eclogite - gneiss and eclogite-schist, 7 - granulite - metabasitic. Names of Lower Precambrian metamorphic complexes: 1 Marunkeu, 2 - Malyk, 3 - Harbey, 4 - Kharamatalou, 5 Khordyu, 6 - Nerkayu, 7 - Nyartin, 8 - Mikulkin. Ural lateral raise: $I$ - Sobskoe, II - Kozhimskoe. The research areas are marked with rectangles.] 
Института геофизики УрО РАН, ВСЕГЕИ, ОАО “Баженовской геофизической экспедиции” и другие. Для извлечения информации о глубоких слоях литосферы они широко используют результаты интерпретации геофизических полей. В своих работах исследователи большое внимание уделяют разработке методик интерпретации геофизических полей $[10,11]$, а также вопросами тектоники, нефтегазоносности и металлогении $[12,13,14]$.

В настоящей статье с целью проверки гипотезы о том, что эклогитсодержащие комплексы севера Урала могут являются отторженцами древнего докембрийского фундамента, дается сравнительный анализ геофизических полей над марункеуским и неркаюским комплексами, рассматриваются возможные глубинные связи высокобарических объектов и кристаллического фундамента прилегающей с запада платформенной области.

\section{Краткая геологическая характеристика эклогитсодержащих комплексов севера Урала}

Марункеуский эклогит-гнейсовый комплекс слагает северную часть Харбейско-Марункеуского блокантиклинория (рис. 1). Он находится к западу от Сыумкеуского гипербазитового массива, входящего в состав палеозойской офиолитовой ассоциации и отделен от него Главным Уральским разломом. Комплекс на западе, северо-западе и востоке имеет тектонические взаимоотношения с вулканогенно-осадочными образованиями верхнего докембрия, которые ранее относились к мезо- и неопротерозою [15], но в последнее время на основании результатов U-Pb датирования детритовых цирконов из терригенной части разреза установлена их принадлежность к верхам неопротерозоя $[16,17]$. На юге Марункеуский комплекс по Хадата-Лонготскому разлому граничит с палеопротерозойскими образованиями харбейского гнейсо-мигматитового комплекса.

В строении марункеуского комплекса участвуют эклогиты, симплектит-эклогиты и апоэклогитовые амфиболиты, метаперидотиты, а также плагиогнейсы, плагиомигматиты и K-Na мигматиты. Породы многократно дислоцированы и преобразованы последовательно проявившимися метаморфическими процессами. Фрагменты наиболее ранних структурных элементов представлены линейными складками преимущественно западно-северо-западной ориентировки. Возраст протолитов эклогитов, судя по имеющимся максимальным значениям датировок пород и минералов, превышает 1.8 млрд лет, однако, вопрос о времени проявления метаморфизма эклогитовой фации остается спорным. По оценке В. Л. Андреичева с соавторами [18] разделяемой авторами настоящей статьи, он не менее 1.68 млрд лет и, скорее всего, близок к значению 1.86 млрд лет, полученному U-Pb методом (циркон, SHRIMP-II [19]). Дж. Глодни с соавторами [20] ограничивают его интервалом 362-353 млн лет. А. Л. Коноваловым и его коллегами [21] по единичным цирконам из эклогитов (по габбровому субстрату) получен конкордантный U-Pb возраст
$485.4 \pm 4.0$ млн лет и $392 \pm 13$ млн лет (из светлых оторочек зерен циркона). Последняя датировка, по мнению упомянутых исследователей, указывает на вероятное время формирования эклогитов.

Неркаюский эклогит-сланцевый комплекс находится на восточном склоне Приполярного Урала и слагает одноименный тектонический блок (рис. 1). На востоке он контактирует с габбро и ультраосновными породами Олыся-Мусюрского массива по Главному Уральскому разлому, а на западе - вдоль Эрепшорского разлома со слабометаморфизованными вулканогенно-осадочными отложениями керегшорского вулканогенно-осадочного комплекса, предположительно мезо-неопротерозойского возраста [7].

Комплекс сложен эклогитами, амфиболитами, гранат-слюдяными кристаллическими сланцами и продуктами их низкотемпературного диафтореза: хлоритэпидот-актинолитовыми и хлорит-мусковит-альбиткварцевыми сланцами. Как и в марункеуском комплексе породы неркаюского комплекса многократно дислоцированы и преобразованы последовательно проявившимися метаморфическими процессами. Фрагменты наиболее ранних структурных элементов представлены линейными складками субширотной и западно-северо-западной ориентировки.

Вопрос о возрасте вулканогенно-осадочного субстрата неркаюского комплекса и времени проявления процессов метаморфизма пород остается дискуссионным. К. С. Ивановым и его соавторами [22] возраст высокобарического метаморфизма пород на основании Ar$\mathrm{Ar}$ датировок белых слюд из эклогитов оценивается значениями $351.3 \pm 3.6$ и $352 \pm 3.6$ млн лет. Выполненное недавно датирование двух проб (по 50 зерен цирконов в каждой) из кристаллических сланцев U-Pb методом с использованием лазерной абляции и магнитно-секторной масс-спектрометрии с индуктивно-связанной плазмой (LA-ICP-SF-MS) показало разброс возрастных определений в интервале 2716-534 млн лет [23]. Верхний возрастной уровень терригенных образований протолитов гранат-слюдяных кристаллических сланцев - превышает 2.0 млрд лет. Это подтверждается как возрастом наиболее «молодых» зерен детритовых цирконов (2012-2009 млн лет), так и наиболее древними датировками метаморфогенных цирконов (2008-2004 млн лет). Учитывая, что пластовые тела эклогитов участвуют в строении наиболее ранних складок, а парагенезис гранат+омфацит в метабазитах относится к образованиям наиболее ранних метаморфических событий $[2,7,24]$, возрастной репер - около 2.0 млрд лет можно связать с проявлением эклогитового метаморфизма. Полимодальное распределение более молодых возрастных определений с максимумами около 1.5, 1.25, 1.0 и 0.65 млрд лет обусловлено неоднократным развитием метаморфических процессов в породах неркаюского комплекса [23].

\section{Методика исследований}

Для решения поставленной задачи были проведены комплексные петрофизические, геофизические и геологические исследования. Процесс моделирования 
сводился к поэтапной интерпретации грависейсмических данных. На первом этапе большое внимание было уделено гравиметрии как одному из глубинных методов, с помощью которого необходимо было выяснить, к какому структурному этажу относятся источники положительных аномалий над эклогитсодержащими комплексами. Вопрос о глубине залегания аномальных масс земной коры решается методом последовательного исключения аномальных составляющих из наблюденного гравитационного поля [25]. Выделение локальных аномалий выполнялось по методу Андреева-Гриффинга для верхней и нижней частей разреза земной коры. Результаты первого этапа представлены трансформационными картами локальных аномалий.

На втором этапе применялась методика комплексной интерпретации геофизических полей. Грависейсмическое моделирование на территории Южного, Среднего и Северного Урала в последнее десятилетие успешно применяется специалистами, занимающимися вопросами глубинного строения [10, 11, 13]. В данной работе использована методика построения глубинных плотностных моделей земной коры и верхней мантии, программное обеспечение которой разработано Г. Я Голиздрой [26]. Для поставленных целей использовались аппроксимационные модели: слой и многогранник с плоскими гранями. Для представления первоначальной модели среды использовались как петрофизические данные пород эклогитсодержащих комплексов, так и корреляционные зависимости $\sigma=$ $\mathrm{f}(\mathrm{Vp})$ для разных сейсмогеологических этажей [27]. Затем методом подбора, меняя границы многоугольников (полигонов) и плотность, добиваются совпадения наблюденного и вычисленного поля силы тяжести. В процессе интерпретации использовались карты гравитационного поля масштаба 1:200000 и 1:1000000. Более детально результаты комплексной интерпретации гравитационных и сейсмических данных для Полярного Урала приведены в ранних работах [28, 29]. Важно отметить, что в данной работе главное внимание авторов сконцентрировано на геологической интерпретации геофизических данных.

Комплексная интерпретация и последующий анализ результатов интерпретации геофизических полей позволили получить представление о распределении источников геофизических аномалий на определенных глубинных уровнях земной коры севера Урала и, в конечном итоге, выявить взаимосвязи между глубинными и поверхностными марункеуским и неркаюским эклогитсодежащими комплексами, а также между глубинными структурами сопредельной территории.

\section{Обсуждение результатов}

Характер наблюденного гравитационного поля над марункеуским комплексом определяется составом пород с широкими пределами изменения плотностных свойств, ранее детально изученных в процессе петрофизических исследований [4]. Несмотря на существенный разброс значений плотности пород, в целом над всем марункеуским комплексом наблюдается положи- тельное гравитационное поле [5, 30]. Наиболее интенсивное поле наблюдается в южном окончании комплекса, где вскрываются нижние части разреза. Оно представлено изометрическими аномалиями интенсивностью до 70 мГал. Над северным фрагментом структура поля $\Delta \mathrm{g}$ имеет вид параллельных изолиний, которые имеют северо-северо-восточную ориентировку. Различие в морфологии гравитационного поля в южном и северном секторах комплекса наиболее отчетливо проявляется в трансформированных полях. Так, в локальных полях, отражающих распределение плотностных неоднородностей в близповерхностном слое земной коры до глубины 2-3 км, происходит четкое разделение комплекса на южную и северо-восточную части [30]. Над южной частью марункеуского комплекса наблюдается локальный максимум, «ядро» которого слагают породы с высокой плотностью более

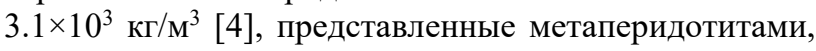
эклогитами и апоэклогитовыми амфиболитами, выходящими на земную поверхность в районе Слюдяной горки. Напротив, над северо-восточной частью марункеуского комплекса отмечаются слабоинтенсивные знакопеременные локальные аномалии, в плане которым отвечают породы кислого состава: плагиогнейсы, гнейсы и продукты их мигматизации с большим разбросом значений плотности от $2.85 \times 10^{3} \mathrm{\kappa} / \mathrm{M}^{3}$ до $2.65 \times 10^{3} \mathrm{\kappa} \Gamma / \mathrm{M}^{3}$.

В локальном поле гравитационных аномалий, отражающих дифференциацию плотностных свойств пород на уровне средней коры (рис. 2), наблюдается только огибающая дугообразно-вытянутая положительная аномалия, которая в плане соотносится с границами выхода пород повышенной плотности (основности) на земной поверхности [5]. Отсутствие в северо-восточной части отрицательных гравитационных аномалий в локальных полях этого глубинного уровня предполагает незначительную глубину залегания пород более кислого состава.

Наиболее интенсивная часть гравитационного поля над марункеуским эклогит-гнейсовым комплексом, вероятно, является юго-восточным окончанием Варандей-Адзьвинской зоны положительных гравитационных аномалий Печорской плиты (рис. 2) [31, 32]. Варандей-Адьзвинская зона захватывает Воркутинскую зону положительных аномалий и расположена вблизи Вашуткинско-Талотинского разлома [33], который на юго-востоке находит свое продолжение в Хадата-Лонготской разломной системе глубокого заложения.

Над неркаюским комплексом положительное наблюденное гравитационное поле по конфигурации (форме и размерам) и интенсивности аномалий также делится на две части $[6,30]:$ северо-восточную и югозападную. С той разницей, что более «аномальной» является его северо-восточная часть, представленная интенсивными положительными аномалиями поля силы тяжести. Аномалии интенсивностью до 60 мГал приурочены к выходам пород основного состава (апоэклогитовые амфиболиты и продукты их низкотемпературного диафтореза) с плотностью более $3.1 \times 10^{3} \mathrm{\kappa г} / \mathrm{M}^{3}$. 


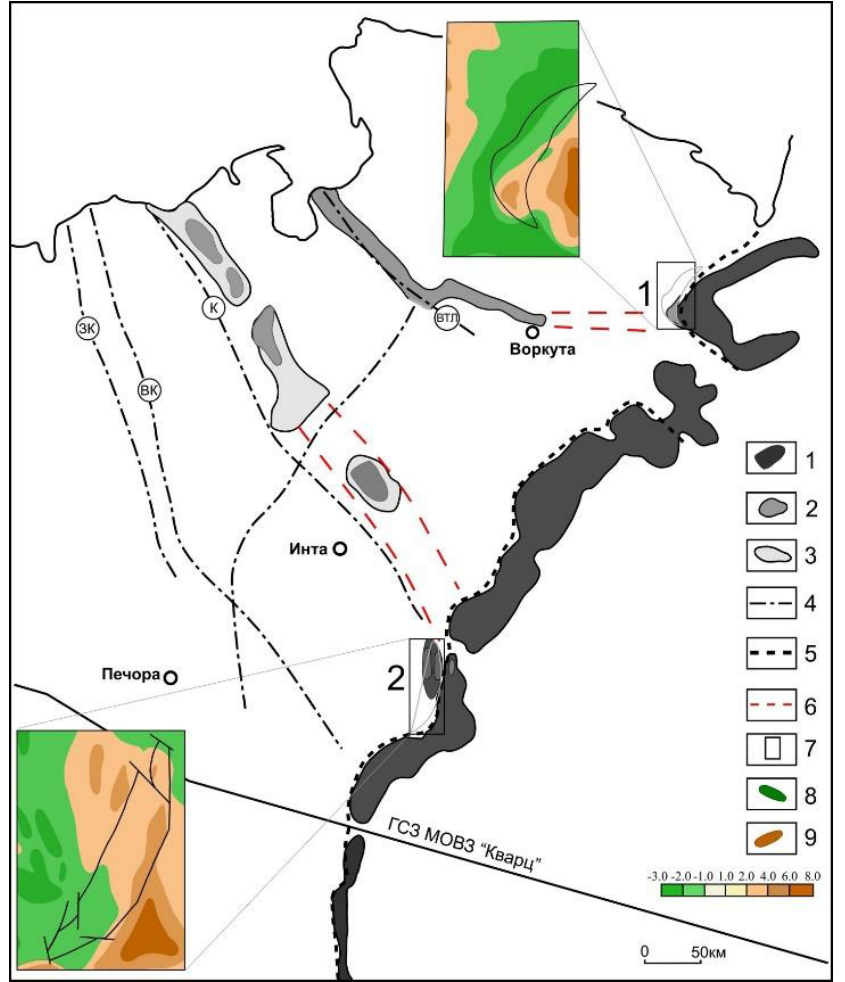

Для юго-западной (верхней) части неркаюского комплекса, где широко распространены слюдистые кристаллические сланцы разного состава и низкотемпературные диафториты по ним со средней плотностью

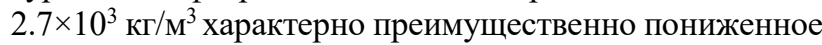
положительное поле силы тяжести. Морфология гравитационного поля юго-западной части комплекса отличается от северо-восточной отсутствием аномалий и представлена в виде параллельных изолиний $\Delta \mathrm{g}_{\mathrm{H}}$. Постепенное понижение интенсивности поля силы тяжести в юговосточном направлении в точности соответствует уменьшению плотности пород этой части комплекса [34].

Структура гравитационного поля еще более дифференцирована в локальных полях: в северо-восточной части комплекса наблюдаются положительные аномалии разной интенсивности, в юго-западной - с выраженным пониженным и отрицательным полем [6]. Наибольшее обособление северо-восточного сегмента в неркаюском комплексе отмечается в локальных полях, существенное влияние на которое оказывают плотностные неоднородности средней коры, расположенные на глубине 12.5-20 км. На карте локальных аномалий (рис. 2) в северо-восточной части комплекса наблюдаются линзовидные положительные аномалии одинаковой интенсивности, объединяющиеся в единую зону северо-западной ориентировки. Выделенная положительная зона, возможно, является юго-восточным продолжением Верхнеколвинской подзоны интенсивных положительных локальных аномалий (рис. 2). По мнению И. В. Запорожцевой и ее соавторов [31,35], источником Верхнеколвинской подзоны гравитационных и магнитных аномалий является резкий подъем к дневной поверхности пород с нижних глубинных уровней земной коры. Доказательством в пользу такого предположения могут
Рис. 2. Упрощенная схема локальных аномалий севера Урала и европейского Северо-Востока, построенная с использованием авторских материалов, а также данных других авторов [31, 32, 33]. Условные обозначения: локальные аномалии средней коры. 1-3 - положительные аномалии: 1 Уральский супермаксимум; 2 - высокоинтенсивные; 3 - интенсивные; 4 - разломы, выделенные по геофизическим данным [33]; 5 - Главный Уральский разлом; тектонические границы эклогитсодержащих комплексов; 6 - предполагаемые гравитационные положительные зоны; 7 - районы исследований; 8-9 - локальные аномалии средней коры эклогитсодержащих комплексов; 8 - отрицательные; 9 - положительные. Объекты исследований (комплексы): 1 - марункеуский эклогит-гнейсовый, 2 - неркаюский эклогит-сланцевый.

[Fig. 2. Simplified scheme of local anomalies in the north of the Urals and the European Northeast, constructed using the author's materials, as well as other authors $[31,32,33]$. Legend: local anomalies of the middle crust. 1-3 - positive anomalies: 1 - Ural supermaximum; 2 - high - intensity; 3 - intense; 4 faults, identified from geophysical data [33]; 5 - Main Uralian Fault; tectonic boundaries of eclogite-containing complexes; $6-$ assumed gravitational positive zones; 7 - study areas; $8-9$ - local anomalies of the middle crust of eclogite-containing complexes; 8 - negative; 9 - positive. The research objects (complexes): 1 Marunkeu eclogite-gneiss, 2 - Nerkayu eclogite-schist.]

послужить данные геоплотностного разреза земной коры и верхней мантии (рис. 3), где регистрируется подъем верхней границы диорито-гнейсового подкомплекса до отметки 8 км от земной поверхности [36, 37]. Важно отметить, что в северо-восточной части Верхнеколвинской подзоны гравитационных аномалий наблюдается резкое изменение характера магнитного поля и повышение горизонтального градиента поля $\Delta \mathrm{g}$, что послужило основанием для выделения Верхнеколвинского разлома [33].

Приведенные выше данные дают основание предполагать наличие возможных связей плотностных неоднородностей в разрезе высокобарических комплексов севера Урала и кристаллического основания Печорской плиты, что может служить дополнительным аргументом в пользу точки зрения о принадлежности марункеуского и неркаюского комплексов к фрагментам раннедокембрийского основания, вовлеченного в структуру Уралид. Структурные, петрографические и геохронологические данные указывают на палеопротерозойский возраст проявления эклогитового метаморфизма (около 2.0-1.9 млрд лет назад). Близкий возрастной уровень (около 1.9 млрд лет) установлен для свекофенского этапа эклогитового метаморфизма в Беломорском подвижном поясе Фенноскандинавского щита $[38,39,40]$. То есть проявление метаморфизма эклогитовой фации в метаморфических комплексах севера Урала, как и на Фенноскандинавском щите, связано с процессами формирования раннедокембрийского кристаллического фундамента, а отмечающиеся палеозойские возрастные датировки в марункеуском и неркаюском комплексах (362-351 млн лет), вероятно, фиксируют относительно поздние этапы эксгумации Марункеуского и Неркаюского блоков, связанные с развитием Уралид. 


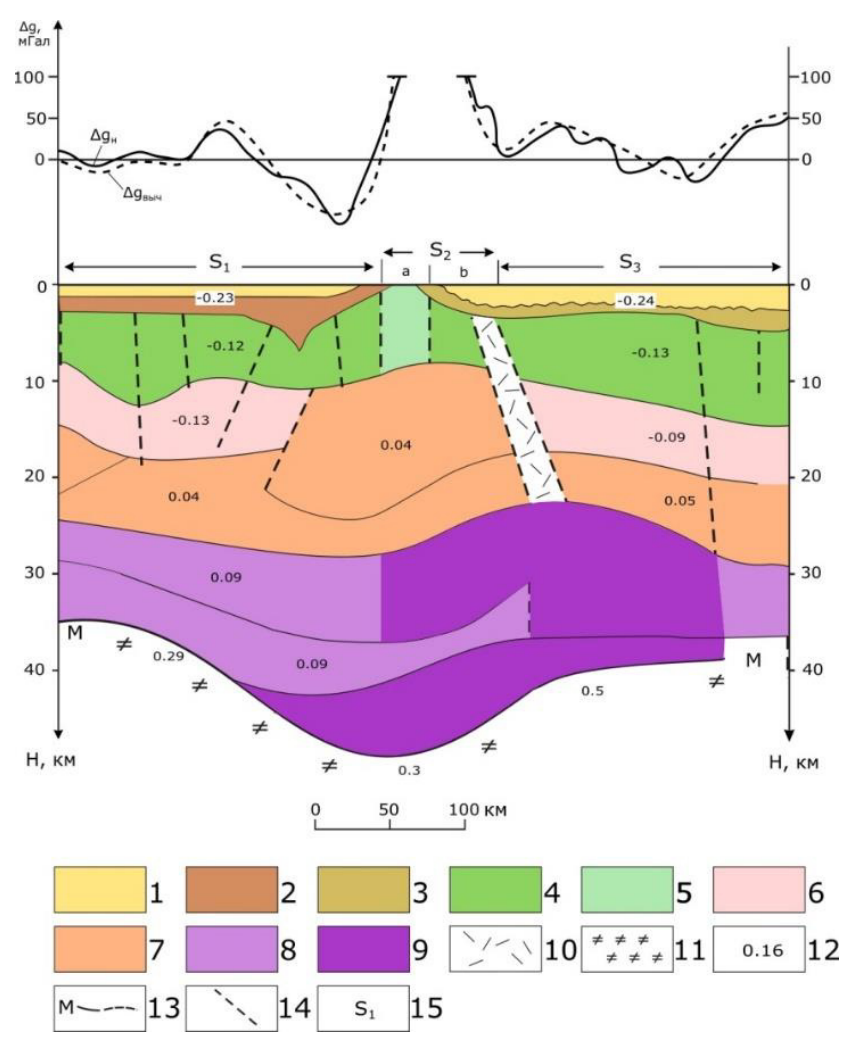

Рис. 3. Фрагмент геоплотностного разреза земной коры и верхней мантии по профилю ГСЗ «КВАРЦ», составленный с использованием материалов других авторов [36]. Условные обозначения: I-III - структуры: I - Печорской плиты; II - складчатого Урала; III - Западно-Сибирской плиты. 1-9 структурно-вещественные комплексы и подкомплексы $[35,28] .1$ - верхний терригенный комплекс Печорской плиты и мезозойско-кайнозойский Западно-Сибирской плиты; 2 - нерасчлененный карбонатно-терригенный комплекс осадочного чехла Печорской плиты; 3 - палеозойский комплекс Западно-Сибирской плиты; 4 - зеленосланцевый комплекс; 5 - вулканогенно-осадочный комплекс; 6-7 - гнейсогранулитовый комплекс: 6 - гранитогнейсовый и 7 - диоритогнейсовый подкомплексы; 8-9 - гранулитометабазитовый комплекс: 8 - собственно гранулито-метабазитовый и 9 - метабазитовый подкомплексы; 10 - зона коровых разломов; 11 - верхняя мантия; 12 - средние эффективные плотности; 13 - граница Мохоровичича; 14 - границы основных структурно-вещественных комплексов, проведенные по сейсмическим (сплошная) и по гравиметрическим (пунктирная линия) данным; 15 - крупнейшие структуры $\left(\mathrm{S}_{1-3}\right): S_{1}-$ Печорская плита; $S_{2}-$ Урал; $S_{3}$ - Западно-Сибирская плита.

[Fig. 3. A fragment of the geodensity section of the earth's crust and upper mantle according to the profile of the GSS "QUARTZ", compiled using materials from other authors [36]. Legend: I-III-structures: I- Pechora Plate; II - folded Urals; III - West Siberian Plate.1-9 - structural-material complexes and subcomplexes $[35,28] .1$ - upper terrigenous complex of the Pechora Plate and Mesozoic-Cenozoic of the West Siberian Plate; 2 - undifferentiated carbonate - terrigenous complex of the sedi-

mentary cover of the Pechora Plate; 3 - Paleozoic complex of theWest Siberian Plate; 4 - green scshist complex; 5 - volcanogenic sedimentary complex; 6-7 - gneissogranulite complex: 6 - granitogneisic and 7 -dioritogneisic subcomplexes; $8-9$ - granulite - metabasite complex: 8 - granulite - metabasite proper and 9 - metabasite subcomplexes; 10 - crustal fault zone; 11 - upper mantle; 12 - average effective densities; 13 - the Mohorovichich boundary; 14 - the boundaries of the main structural-material complexes, drawn from seismic (solid) and gravimetric (dotted line) data; 15 - the largest structures (S1-3): $S_{1}$ - the Pechora Plate; $S_{2}$ - the Urals; $S_{3}-$ the West Siberian Plate.]

\section{Заключение}

1. Высокоинтенсивные участки гравитационного поля над марункеуским и неркаюским комплексами соотносятся с областями преимущественного распространения пород основного (и частично ультраосновного в марункеуском комплексе) состава: эклогитов, эклогитизированных пород и диафторитов по эклогитам.

2. Максимумы в локальных полях $\Delta \mathrm{g}$ над эклогитсодержащими комплексами севера Урала, вероятно, являются юго-восточным продолжением ВарандейАдзьвинской зоны и Верхнеколвинской подзоны интенсивных положительных гравитационных аномалий Печорской плиты.

3. Источники названных положительных аномалий располагаются в верхней и средней частях земной коры и сопряжены с глубинными разломными системами.

4. Полученные данные подтверждают представление о марункеуском и неркаюском комплексах, как фрагментах раннедокембрийского основания, вовлеченного в структуру Уралид.

Благодарности: Авторы глубоко благодарны сотрудникам лаборатории региональной геологии Института геологии Коми НЦ УрО РАН Евгении Валерьевне Кушмановой за предоставленный каменный материал, Наталье Сергеевне Уляшевой и Ирине Игоревне Голубевой за ценные советы и консультации по геологии и петрографии.
Конфликт интересов: Авторы декларируют отсутствие явных и потенциальных конфликтов интересов, связанных с публикацией настоящей статьи.

\section{ЛИТЕРАТУРА}

1. Удовкина Н. Г. Эклогиты Полярного Урала. М.: Наука, $1971.193 \mathrm{c}$.

2. Пыстин А. М, Казак А. П., Чернышев Ю. Я. Эклогиты неркаюского комплекса на Приполярном Урале // Записки BMO. 1983. Ч. 112. Вып. 3. С. 346-353.

3. Вализер П. М., Ленных В. И. Амфиболы голубых сланцев Урала. М.: Наука, 1988. 203 с.

4. Пономарева Т. А., Пыстин А. М. Петрофизическая характеристика пород полиметаморфических комплексов севера Урала // Известия Коми НЦ УрО РАН, 2014. №2 (18). С. 68-74.

5. Пономарева Т.А., Пыстин А.М. Структурные особенности марункеуского эклогит-гнейсового комплекса Полярного Урала по гравимагнитным данным // Вестник Института геологии Коми НЦ УрО РАН, 2019. № 2. С. 14-21. DOI: 10.19110/2221-1381-2019-2-14-21.

6. Пономарева Т. А., Пыстин А. М., Кушманова Е. В. Глубинная характеристика неркаюского эклогит-сланцевого комплекса Приполярного Урала // Вестник Института геологии Коми НЦ УрО РАН, 2017. №11. С. 9-14.

7. Пыстин А.М. Полиметаморфические комплексы западного склона Урала. М: Наука, 1994. 208 с.

8. Пыстин А. М., Пыстина Ю. И., Потапов И. Л., Панфилов А. В. Раннедокембрийская история метаморфизма пород гранулитовых и эклогитовых комплексов палеоконтинентальной зоны Урала. Сыктывкар: Геопринт. 2012. 46 с. 
9. Пыстин А. М., Пыстина Ю. И. Докембрий Приполярного Урала: хроностратиграфический аспект // Труды Карельского научного иентра РАН, Серия: Геология докембрия. 2019. № 2. C. 34-52. DOI: $10.17076 /$ geo 904

10. Колмогорова В. В., Федорова Н. В. Результаты моделирования глубинного строения земной коры по уральской части геотраверса Кварц // Геофизика. 2015. № 6. С. 61-67.

11. Мартышко П. С., Ладовский И. В., Федорова Н. В., Бызов Д. Д., Цидаев А. Г. Теория и методы комплексной интерпретации геофизических данных. Екатеринбург: УрО РАН, $2016.94 \mathrm{c}$.

12. Рыльков С. А., Рыбалка А. В., Иванов К. С. Глубинное строение и металлогения Урала: сопоставление глубинное строение Южного, Среднего и Полярного Урала // Литосфера. 2013. № 1. С. 3-16.

13. Дружинин В. С., Мартышко П. С., Начапкин Н. И., Осипов В. Ю. Строение верхней части литосферы и нефтегазоносность недр Уральского региона. Екатеринбург: ИГФ УрО РАН, 2014. $228 \mathrm{c}$.

14. Пучков В. Н., Иванов К С. Тектоника севера Урала и Западной Сибири: общая история развития // Геотектоника. 2020. № 1. C. 41-61. DOI:10.31857/s0016853×20010105.

15. Стратиграфические схемы Урала (докембрий, палеозой). Екатеринбург: Уралгеолком, 1993. 152 с.

16. Pystin A. M., Pystina Yu. I., Ulyasheva N. S., Grakova O. V. $\mathrm{U}-\mathrm{Pb}$ dating of detrital zircons from basal Post Paleoproterozoic metasediments in the Subpolar and Polar Urals: Evidence for a Cryogenian, not Mesoproterozoic Age // International Geology Review. 2020. Vol. 62. № 17. P. 2189-2202. DOI: 10.1080./00206814.2019.1689533

17. Пыстин А. М, Пыстина Ю. И., Уляшева Н. С., Гракова О. В. Источники сноса и U-Pb возраст обломочных цирконов из верхнепротерозойских отложений Полярного Урала: к вопросу о времени заложения Тиманской пассивной окраины // Стратиграфия. Геологическая коррелящия. 2020. Т.28. № 5. C. 3-25. DOI: 10.31857/S0869592X20050087.

18. Андреичев В. Л., Ронкин Ю. Л., Серов П. А., Лепехина О. П., Литвиненко А.Ф. Новые данные о докембрийском возрасте эклогитов Марункеу (Полярный Урал) // Докл. $A H$. 2007. T. 413. № 4. С. 503-506.

19. Андреичев В. Л, Родионов Н.В., Ронкин Ю.Л. U-Pb и Sm$\mathrm{Nd}$ датирование эклогитов Марункеуского блока Полярного Урала: новые данные. Метаморфизм, космические, экспериментальные и общие проблемы петрологии: материалы Международного (X Всероссийского) петрографического совещания "Петрография XXI века". Апатиты, 20-24 июня 2005. T.4. C. 17-19.

20. Glodny J., Pease V., Montero P., Austrheim H. Rusin A. I. Protolith ages of eclogites, Marun-Keu Complex, Polar Urals, Russia: implications for the pre- and early Uralian evolution of the northeastern European continental margin. // Geological Society of London, Memoir. 2004. Vol. 30. pp. 87-105. https://doi.org/10.1144/GSL.MEM.2004.030.01.09.

21. Коновалов А. Л., Доливо-Добровольский Д. В., Мельгунов А. Н., Казак А. П. Дислокационный метаморфизм протерозойских комплексов Харбейско-Марункеуской структурно-формационной зоны (Полярный Урал) // Региональная геология и металлогения. 2009. № 39. С. 33-45.

22. Иванов К. С., Карстен Л. А., Малюски Г. Первые сведения о возрасте субдукционного (эклогит-глаукофанового) метаморфизма на Приполярном Урале // Палеозоны субдукции: тектоника, магматизм, метаморфизм, седиментогенез: сборник докладов V Международной научной конференции "Чтения А. Н. Заварицкого", посвященной 115-летию со дня рождения А. Н. Заварицкого. Екатеринбург, 1-4 июня 1999. 2000. C. $121-128$.

23. Пыстин А. М., Кушманова Е. В., Пыстина Ю. И., Панфилов А. В., Потапов И. Л. Возраст протолитов и геохронология метаморфизма неркаюского эклогит-сланцевого комплекса Приполярного Урала // Вестник Пермского университета. Серия: Геология. 2019. Т. 18. № 2 С. 96-107. DOI: 10. 17072/psu.geol.18.2.96.

24. Пыстин А. М., Кушманова Е. В., Потапов И. Л., Панфилов А. В. Неркаюский метаморфический комплекс Приполярного Урала. // Вестник ИГ Коми НЦ УрО РАН. №11. 2014. С. 22-27.

25. Маловичко А. К., Тарунина О. Л. Использование высших производных при обработке и интерпретации результатов геофизических наблюдений. М: Недра, 1981. 186 с.

26 Голиздра Г. Я. Комплексная интерпретация геофизических полей при изучении глубинного строения земной коры. М: Недра, 1988. 212 с.

27. Семенов Б. Г. Зависимость плотность-скорость и учет термодинамических условий при построении плотностной модели земной коры и верхней мантии // Геология и геофизика. 1983. № 6. С. 90-98.

28. Лыюрова (Пономарева) Т.А, Конанова Н.В. Пример комплексной интерпретации физических полей с целью изучения глубинного строения земной коры Войкаро-Сынинского масива // Геология севера Урала. Труды Института геологии. Вып.78. Сыктывкар, 1992. С. 97-105.

29. Лыюрова (Пономарева) Т. А. Глубинное строение Полярного Урала: Автореф. дис. ... канд. геол.-мин. наук. Сыктывкар, $1997.16 \mathrm{c}$.

30. Пономарева Т. А. Структурные особенности эклогитсодержащих комплексов севера Урала по гравимагнитным данным / Вестник Пермского университета: Серия геологическая, 2020. №1(19). С. 25-37. DOI: 10.17072/psu.geol.19.1.25 31. Дедеев В. А., Запорожцева И. В. Земная кора европейского Северо-Востока СССР, Л.: Наука. 1985.98 с.

32. Берлянд Н. Г., Запорожцева И. В. О глубинном строении области сочленения севера Урала и Восточно-Европейском платформы // ДАН СССР, 1982а. Т. 263. № 5. С. 1186-1189.

33. Малышев Н. А. Разломы европейского Северо-Востока СССР в связи с нефтегазоносностью. Л.: Наука, 1986. 112 с.

34. Пономарева Т. А., Пыстин А. М. Анализ физических свойств пород Восточной зоны севера Урала // Известия Коми НЦ УрО РАН. 2016. №1(25). С. 51-61.

35. Запорожцева И. В., Пыстин А. М. Строение дофанерозойской литосферы европейского Северо-Востока России. СПб.: Наука, 1994. 112 с.

36. Егоркин А. В. Строение земной коры по сейсмическим геотраверсам // Глубинное строение территории СССР. М.: Наука, 1991. С. 118-135.

37. Лыюрова (Пономарева) Т. А., Конанова Н. В. Геоплотностные модели литосферы Печорской и севера Западно-Сибирской плит. Сыктывкар: Коми НЦ УрО РАН. 1993. 20 с.

38. Скублов С. Г. Астафьев Б. Ю., Маринин Ю. Б., Березин А. В., Мельник А. Е., Пресняков С. Л. Новые данные о возрасте эклогитов Беломорского подвижного пояса в районе с. Гридино // Докл. АН. 2011. Т. 439. № 6. С. 795-802.

39. Мельник А. Е., Скублов С. Г., Березин А. В., Богомолов Е. С., Марин Ю.Б. Новые данные о возрасте (U-Pb, Sm-Nd) метаморфизма и протолита эклогитопаодобных пород района Красной Губы, Беломорский пояс // Докл. АН. 2013. Т. 453. № 3. С. 319-325.

40. Скублов С. Г., Березин А. В., Мельник А. Е., Астафьев Б. Ю., Воинова О. А., Алексеев В. И. // Петрология. 2016. Т. 24. № 6. C. 640-653. 


\title{
Structural relations of eclogite complexes of the northern part of the Urals with the crystalline basement of the Pechora plate
}

\author{
C2021 T. A. Ponomareva ${ }^{\bowtie}$, A. M. Pystin \\ Institute of Geology named after Academician N. P. Yushkin of Komi Science centre of Ural Branch of
Russian Academy of sciences, 54 ul. Pervomayskaya, Syktyvkar 167000, GSP-2, Russian Federation
}

\begin{abstract}
Introduction: Eclogites were found in the north of the Ural in two metamorphic complexes: the Marunkeu eclogite-gneiss complex in the Polar Urals and the Nerkayu eclogite-shale complex in the Nether-Polar Urals. The features of north-western and near east-west orientation of the anomalies of the geophysical fields and their spatial correlations were found above the eclogite complexes of the northern part of the Urals. Structural features and geological relations between the complexes and the surrounding strata allow supporting the hypothesis that the Marunkeu and Nerkayu complexes belong to the fragments of Precambrian basement involved in the structure of the Uralides. A comprehensive interpretation of geophysical fields is presented for the Marunkeu and Nerkayu complexes. We consider the possible deep relations between high-pressure objects and the crystalline basement of the platform region adjacent from the west. Methodology: The data from the comprehensive interpretation of geophysical fields (gravitational and seismic) were consolidated and systemised, which allows solving the issue of the depth of occurrence of the sources of anomalies above eclogite complexes. We focused on the analysis of the transformed maps and construction by the selection of a complex model of the Earth's crust as well as the geological interpretation of deep structures.

Results and discussions: The interpretation of the gravitational field allowed identifying similar features in the structure of the Marunkeu eclogite-gneiss complex and the Nerkayu eclogite-schist complex. The local gravity maxima were confined to the areas of prevalence of the rocks of the basic (and partially ultramafic in the Marunkeu complex) composition. The study of the structure of local fields by intensity, size, and linear northwestern direction of anomalous zones and subzones of the Pechora plate and eclogite complexes of the northern part of the Urals allowed establishing a spatial correlation between them at the medium crust level.

Conclusions: The identified spatial correlations allow considering the most anomalous areas above the Marunkeu eclogite-gneiss complex and the Nerkayu eclogite-schist complex to be a south-eastern extension of the Varandey-Adzva zone and Verkhnekolvinskaya subzone of intensive positive gravitational anomalies of the Pechora plate. The obtained geological and geophysical data confirm the idea that the Marunkeu and the Nerkayu complexes are fragments of the Precambrian basement involved in the structure of the Uralides.
\end{abstract}

Keywords: geophysical fields, north of the Urals, Marunkeu, Nerkayu, complex, deep structure, anomaly, fault, zone.

Funding: The study was supported by R\&D programs of the GR No. AAAA-A17-117121270035-0.

For citation: Ponomareva T. A., Pystin A. M. Structural relations of eclogite complexes of the northern part of the Urals with the crystalline basement of the Pechora plate. Vestnik Voronezhskogo gosudarstvennogo universiteta. Seriya: Geologiya - Proceedings of Voronezh State University. Series: Geology, 2021, no. 1, pp. 65-74. DOI: https://doi.org/10.17308/geology.2021.1/3338

\footnotetext{
Tatiana A. Ponomareva, e-mail: taponomareva@inbox.ru
} 


\section{REFERENCES}

1. Udovkina N. G. Ehklogity Polyarnogo Urala [Eclogites of the Polar Urals]. Moscow, Nauka publ., 1971. 193 p. (in Russ.).

2. Pystin A. M., Kazak A. P., Chernyshev Ju. A. Ehklogity nerkayuskogo kompleksa na Pripolyarnom Urale [Eclogites of Nerkayu complex in the Polar Urals]. Zapiski VMO - WMO Notes. 1983, vol. 112, no. 3, pp. 346-353. (in Russ.)

3. Valizer P. M., Lennykh V. I. Amfiboly golubykh slantsev Urala [Amphiboles of the blue schists of the Urals]. Moscow. Nauka publ, 1988. 203 p. (in Russ.)

4. Ponomareva T. A., Pystin A. M. Petrofizicheskaya kharakteristika porod polimetamorficheskikh kompleksov severa Urala [Petrophysical characteristics of rocks of polymetamorphic complexes in the north of the Urals]. Izvestiya Komi NTs UrO RAN Proceedings of the Komi Science Centre of the Ural Division of the Russian Academy of Sciences, 2014, no. 18. pp. 68-74. (in Russ.)

5. Ponomareva T. A., Pystin A. M. Strukturnye osobennosti marunkeuskogo ehklogit-gneisovogo kompleksa Polyarnogo Urala po gravimagnitnym dannym [Structural features of the Marunkeu eclogite-gneiss complex of the Polar Urals based on gravi-magnetic data]. Vestnik Instituta geologii Komi NC UrO RAN - Vestnik of the Institute of Geology of the Komi Science Centre UB RAS , 2019, no. 2. pp. 14-21. (in Russ.) DOI: 10.19110/2221-1381-2019-2-14-21.

6. Ponomareva T. A., Pystin A. M., Kushmanova E. V. Glubinnaya kharakteristika nerkayuskogo ehklogit-slantsevogo kompleksa Pripolyarnogo Urala [Deep characteristics of the Nerkayu eclogite-schist complex of the Nether-Polar Urals]. Vestnik Instituta geologii Komi NC UrO RAN - Vestnik of the Institute of Geology of the Komi Science Centre UB RAS, 2017, no. 11, pp. 914. (in Russ.)

7. Pystin A. M. Polimetamorficheskie kompleksy zapadnogo sklona Urala [Polymetamorphic complexes of the western slope of the Urals] Moscow, Nauka publ., 1994, 208 p. (in Russ.).

8. Pystin A. M., Pystina Yu. I., Potapov I. L. Panfilov A. V. Rannedokembriiskaya istoriya metamorfizma porod granulitovykh i ehklogitovykh kompleksov paleokontinental'noi zony Urala [Early Precambrian history of metamorphism of rocks of granulite and eclogite complexes of the paleocontinental zone of the Urals]. Syktyvkar, Geoprint publ., 2012, 46 p. (in Russ.).

9. Pystin A. M., Pystina Yu. I. Dokembrii Pripolyarnogo Urala: khronostratigraficheskii aspekt [Precambrian of the Nether-Polar Urals: chronostratigraphical aspect]. Trudy Karel'skogo nauchnogo tsentra RAN, Seriya: Geologiya dokembriya - Proceedings of the Karelian Scientific Center of the Russian Academy of Sciences, Series: Precambrian Geology, 2019, no.2, pp. 34-52. DOI: 10.17076/geo904. (in Russ.).

10. Kolmogorova V. V., Fedorova N. V. Rezul'taty modelirovaniya glubinnogo stroeniya zemnoi kory po ural'skoi chasti geotraversa Kvarts [Results of modeling the deep structure of the Earth's crust in the Ural part of the Quartz geotraverse]. Geofizika - Geophysics, 2015, no. 6. pp. 61-67. (in Russ.).

11. Martyshko P. S., Ladovskii I. V., Fedorova N. V., Byzov D. D., Tsidaev A. G. Teoriya i metody kompleksnoi interpretatsii geofizicheskikh dannykh [Theory and methods of complex interpretation of geophysical data]. Ekaterinburg: UrO RAN publ., 2016, 94 p. (in Russ.).

12. Rylkov S. A., Rybalka A. V., Ivanov K. S. Glubinnoe stroenie $i$ metallogeniya Urala: sopostavlenie glubinnoe stroenie $\mathrm{Yu}$ zhnogo, Srednego i Polyarnogo Urala [Deep structure and metallogeny of the Urals: comparison deep structure of the Southern, Middle and Polar Urals]. Litosfera-Lithosphere, 2013, no. 1. pp. 3-16. (in Russ.).

13. Druzhinin V. S., Martyshko P. S., Nachapkin N. I., Osipov V.
Yu. Stroenie verkhnei chasti litosfery i neftegazonosnost' nedr Ural'skogo regiona [The structure of the upper part of the lithosphere and the oil and gas content of the subsurface of the Ural region]. Yekaterinburg, IGF UrO RAS publ., 2014, 228 p. (in Russ.).

14. Puchkov V. N., Ivanov K. S. Tektonika severa Urala i Zapadnoi Sibiri: obshchaya istoriya razvitiya [Tectonics of the North of the Urals and Western Siberia: a general history of development]. Geotektonika, 2020, no. 1. pp. 41-61. DOI:10.31857/s0016853x20010105.

15. Stratigraficheskie skhemy Urala (dokembrii, paleozoi) [Stratigraphic charts of the Urals (Precambrian, Paleozoic)]. Ekaterinburg: Uralgeolkom publ., 1993, 152 p. (in Russ.).

16. Pystin A. M., Pystina Yu. I., Ulyasheva N. S., Grakova O. V. $\mathrm{U}-\mathrm{Pb}$ dating of detrital zircons from basal Post Paleoproterozoic metasediments in the Subpolar and Polar Urals: Evidence for a Cryogenian, not Mesoproterozoic Age. International Geology Review. 2020, vol. 62, no 17, pp. 2189-2202.DOI: 10.1080./00206814.2019.1689533

17. Pystin A. M., Ulyasheva N. S., Pystina Yu. I., Grakova O. V. Provenance area and $\mathrm{U}-\mathrm{Pb}$ age of detrital zircons from the Upper Proterozoic deposits of the Polar Urals: to the question of the time of formation of the Timan passive margin. Stratigraphy and Geological Correlation. 2020, vol. 28, no. 5, pp. 3-25. DOI: 10.31857/S0869592X20050087 (in Russ.).

18. Andreichev V. L., Ronkin Y. L., Serov P. A., Lepikhina O. P., Litvinenko A. F. New data on the Precambrian age of Marunkeu eclogites (Polar Urals). Doklady Earth Sciences. 2007, vol. 413, no. 3, pp. 347-350. DOI: 10.1134/S1028334X07030051.

19. Andreichev V. L., Rodionov N. V., Ronkin Ju. L. U-Pb i SmNd datirovanie ehklogitov Marunkeuskogo bloka Polyarnogo Urala: novye dannye [U-Pb and $\mathrm{Sm}-\mathrm{Nd}$ dating of eclogites of the Marunkeu block of the Polar Urals: new data]. Metamorfizm, kosmicheskie, ehksperimental'nye $i$ obshchie problemy petrologii: materialy Mezhdunarodnogo (KH Vserossiiskogo) petrograficheskogo soveshchaniya "Petrografiya XXI veka", 2005, v. 4, pp. 17-19. (in Russ.).

20. Glodny J., Pease V., Montero P., Austrheim H. Rusin A. I. Protolith ages of eclogites, Marun-Keu Complex, Polar Urals, Russia: implications for the pre- and early Uralian evolution of the northeastern European continental margin. Geological Society of London. Memoir, 2004, v. 30. pp. 87-105. https://doi.org/10.1144/GSL.MEM.2004.030.01.09

21. Konovalov A. L., Dolivo-Dobrovol'skii D. V., Mel'gunov A. N., Kazak A. P. Dislokatsionnyi metamorfizm proterozoiskikh kompleksov Kharbeisko-Marunkeuskoi strukturno-formatsionnoi zony (Polyarnyi Ural) [Dislocation metamorphism of Proterozoic complexes of the Harbiy-Marunkeu structural-formation zone (Polar Ural Mountains)]. Regional'naya geologiya $i$ metallogeniya - Regional geology and metallogeny, 2009, no. 39, pp. 33-45. (in Russ.).

22. Ivanov K. S., Karsten L. A., Malyuski G. Pervye svedeniya o vozraste subduktsionnogo (ehklogit-glaukofanovogo) metamorfizma na Pripolyarnom Urale [First data on the age of subduction (eclogite-glaucophane) metamorphism in the Nether-Polar Urals]. Paleozony subduktsii: tektonika, magmatizm, metamorfizm, sedimentogenez: sbornik dokladov V Mezhdunarodnoi nauchnoi konferentsii "Chteniya A. N. Zavaritskogo" [Paleozones of subduction: tectonics, magmatism, metamorphism, sedimentogenesis: collection of reports In the International Scientific Conference "Readings of A. N. Zavaritsky]. Ekaterinburg. UrO RAN, 2000, pp. 121-128. (in Russ.).

23. Pystin A. M., Kushmanova E. V., Pystina Yu. I., Panfilov A. V., Potapov I. L. Vozrast protolitov i geokhronologiya meta- 
morfizma nerkayuskogo ehklogit-slantsevogo kompleksa Pripolyarnogo Urala [Age of protolithes and geochronology of metamorphism of the Nerkayuskiy eclogite-schist complex of the Subpolar Urals]. Vestnik Permskogo universiteta. Seriya: Geologiya - Bulletin of Perm university. Geology, 2019, v. 18, no. 2, pp. 96107. DOI: 10. 17072/psu.geol.18.2.96 (in Russ.).

24. Pystin A.M., Kushmanova E. V., Potapov I. L., Panfilov A. V. Nerkayuskii metamorficheskii kompleks Pripolyarnogo Urala [The Nerkayu metamorphic complex in the Polar Urals]. Vestnik Instituta geologii Komi NC UrO RAN - Vestnik of the Institute of Geology of the Komi Science Centre UB RAS, 2014, no. 11, pp. 14-19. (in Russ.).

25. Malovichko A. K, Tarunina O. L. Ispol'zovanie vysshikh proizvodnykh pri obrabotke $i$ interpretatsii rezul'tatov geofizicheskikh nablyudenii [The use of higher derivatives in processing and interpreting the results of geophysical observations] Moscow, Nedra publ., 1981, 186 p. (in Russ.).

26. Golizdra G. Y. Kompleksnaya interpretatsiya geofizicheskikh polei pri izuchenii glubinnogo stroeniya zemnoi kory [Integrated interpretation of geophysical fields in the study of the deep structure of the crust]. Moscow, Nedra, 1988, 212 p. (in Russ.).

27. Semenov B. G. Zavisimost' plotnost'-skorost' $i$ uchet termodinamicheskikh uslovii pri postroenii plotnostnoi modeli zemnoi kory $i$ verkhnei mantii [Density-velocity dependence and consideration of thermodynamic conditions in the construction of a density model of the Earth's crust and upper mantle]. Geologiya $i$ geofizika-Geology and Geophysics, 1983, no. 6. pp. 90-98. (in Russ.).

28. Lyyurova (Ponomareva) T.A, Konanova N.V. Primer kompleksnoi interpretatsii fizicheskikh polei s tsel'yu izucheniya glubinnogo stroeniya zemnoi kory Voikaro-Syninskogo masiva [An example of a complex interpretation of physical fields in order to study the deep structure of the zensoy crust of the VoikaroSyninsky massif]. Geologiya severa Urala. Trudy Instituta geologii - Geology of the North of the Urals. Proceedings of the Institute of Geology. Syktyvkar, 1992, pp. 97-105. (in Russ.). 29. Lyyurova (Ponomareva) T. A. Glubinnoe stroenie Polyarnogo Urala. Avtoref. dis. kand. geol.-min. nauk. [The deep structure of the Polar Urals. Abstract Diss. PhD in geol.-min.] Syktyvkar, 1997. 16 p. (in Russ.).

30. Ponomareva T. A. Strukturnye osobennosti ehklogitsoderzhashchikh kompleksov severa Urala po gravimagnitnym dannym [Structural features of eclogite-containing complexes of the North of the Urals according to gravimagnetic data]. Vestnik Permskogo universiteta: Seriya geologicheskaya - Bulletin of Perm university. Geology, 2020, no. 1(19). pp. 25-37. DOI: 10.17072/psu.geol.19.1.25
31. Dedeev V. A., Zaporozhtseva I. V. Zemnaya kora evropeiskogo Severo-Vostoka SSSR [The earth's crust of the European North-East of the USSR]. Leningrad, Nauka publ., 1985, 98 p. (in Russ.).

32. Berlyand N. G., Zaporozhtseva I. V. O glubinnom stroenii oblasti sochleneniya severa Urala $i$ Vostochno-Evropeiskom platformy [On the deep structure of the junction region of the north of the Urals and the Eastern European Platform]. DAN $S S S R, 1982$, v. 263 , no. 5, pp. 1186-1189. (in Russ.).

33. Malyshev N. A. Razlomy evropeiskogo Severo-Vostoka SSSR $v$ svyazi s neftegazonosnost'yu [Faults of the European North-East of the USSR in connection with oil and gas potential]. Leningrad, Nauka publ., 1986. 112 p. (in Russ.).

34. Ponomareva T. A., Pystin A. M. Analiz fizicheskikh svoistv porod Vostochnoi zony severa Urala [Analysis of physical properties of rocks in the eastern zone of the north of the Urals]. Izvestiya Komi NTs UrO RAN - Proceedings of the Komi Science Centre of the Ural Division of the Russian Academy of Sciences, 2016, no.1 (25), pp. 51-61. (in Russ.).

35. Zaporozhtseva I. V., Pystin A. M. Stroenie dofanerozoiskoi litosfery evropeiskogo Severo-Vostoka Rossii [The structure of the Pre-Phanerozoic lithosphere of European north-east of Russia]. SPb, Nauka publ., 1994, 112 p. (in Russ.).

36. Egorkin A. B. Stroenie zemnoi kory po seismicheskim geotraversam [Structure of the earth's crust by seismic data]. Glubinnoe stroenie territorii SSSR. Moscow, Nauka publ., 1991, pp.118134. (in Russ.).

37. Lyyurova (Ponomareva) T. A., Konanova N. V. Geoplotnostnye modeli litosfery Pechorskoi i severa Zapadno-Sibirskoi plit [Geo-density models of the Pechora lithosphere and the north of the West Siberian Plate]. Syktyvkar, Komi SC UrO RAN publ., 1993, 20 p. (in Russ.).

38. Skublov S. G., Astaf'ev B. Yu., Berezin A. V., Marin Yu. B., Mel'nik A. E., Presnyakov S. L. New data on the age of eclogites from the Belomorian mobile belt at Gridino settlement area. Doklady nauk o Zemle - Doklady Earth Sciences, 2011, v. 439, no. 2, pp. 1163-1170.

39. Mel'nik A. E., Skublov S. G., Berezin A. V., Bogomolov E.S., Marin Yu.B. New data on the age (U-Pb, Sm-Nd) of garnetites from salma eclogites of the Belomorian mobile belt. Doklady nauk o Zemle - Doklady Earth Sciences, 2013, v. 448, no. 1, pp. 78-85.

40. Skublov S. G. Berezin A. V., Melnik A. E., Astafiev B. Y., Alekseev V. I., Voinova O. A. Protolith age of eclogites from the southern part of Pezhostrov island, Belomorian belt: protolith of metabasites as indicator of eclogitization time. Petrologija $-P e$ trology, 2016, v. 24, no. 6, pp. 594-607.
Пономарева Татьяна Анатольевна - к.г.-м.н, с. н. с., Институт геологии им. академика Н. П. Юшкина ФИЦ Коми научного центра Уральского отделения Российской академии наук, Сыктывкар; E-mail: taponomareva@inbox.ru; ORCID https://orcid.org/0000-0001-6895-5450

Пыстин Александр Михайлович - д.г.-м.н; г.н.с., Институт геологии им. академика Н.П. Юшкина ФИЦ Коми научного центра Уральского отделения Российской академии наук, Сыктывкар; E-mail: pystin.48@mail.ru ORCID https://orcid.org/0000-0002-5875-4353

Авторы прочитали и одобрили окончательный вариант рукописи.
Tatyana A. Ponomareva - PhD in Geology and Mineralogy, senior research fellow, Institute of Geology of Komi Science Center of the Ural Branch of the Russian Academy of Sciences, Syktyvkar, e-mail: taponomareva@inbox.ru; ORCID https://orcid.org/0000-0001-6895-5450

Alexander M. Pystin - Dr. habil in Geology and Mineralogy, Professor, Institute of Geology of Komi Science Center of the Ural Branch of the Russian Academy of Sciences, Syktyvkar, e-mail: pystin.48@mail.ru ORCID https://orcid.org/0000-0002-5875-4353

All authors have read and approved the final manuscript. 